Article

\title{
Efficiency of Small Scale Manually Fed Boilers -Mathematical Models
}

\author{
Nebojsa Dedovic ${ }^{1{ }^{*},}$, Sasa Igic ${ }^{2}$, Todor Janic ${ }^{1}$, Snezana Matic-Kekic ${ }^{1}$, Ondrej Ponjican ${ }^{1}$, \\ Milan Tomic ${ }^{1}$ and Lazar Savin ${ }^{1}$
}

1 Faculty of Agriculture, University of Novi Sad, Trg Dositeja Obradovica 8, Novi Sad 21000, Serbia; E-Mails: jtodor@polj.uns.ac.rs (T.J.); snmk@polj.uns.ac.rs (S.M.-K.); ponio@polj.uns.ac.rs (O.P.); milanto@polj.uns.ac.rs (M.T.); savlaz@polj.uns.ac.rs (L.S.)

2 Faculty for Economics and Engineering Management, University Business Academy, Cvecarska 2, Novi Sad 21000, Serbia; E-Mail: sasaigic@uns.ac.rs

* Author to whom correspondence should be addressed; E-Mail: dedovicn@polj.uns.ac.rs; Tel.: +381-21-485-3-292.

Received: 27 February 2012; in revised form: 17 April 2012 / Accepted: 3 May 2012 / Published: 15 May 2012

\begin{abstract}
This study reviews test results for a biomass-fired hot water boiler with a nominal boiler thermal power of $120 \mathrm{~kW}$. In the experiments, prismatic wheat straw bales were used as biomass. The impact of the quantity $\left(220,290,360\right.$ and $\left.430 \mathrm{~m}^{3} \mathrm{~h}^{-1}\right)$ of inlet air fed to the boiler firebox was continuously monitored. This was to examine the influence of the quantity of inlet air and recirculation $(0,16.5$ and $33 \%)$ of combustion products on the boiler thermal power and boiler energy efficiency. Thus, the following mathematical models and formulas were presented: correlation between boiler thermal power and bale residence time; bale mass loss during the combustion process; correlation between boiler energy efficiency and bale residence time. Mathematical models were obtained by using experimental data and by applying nonlinear regression analysis. Adjustment evaluation of mathematical models with experimental data was performed based on the determination coefficient, $t$-test and $F$-test. Increase the amount of air throughout the firebox produced boiler thermal power increase and bale residence time decrease. It was shown that combustion products recirculation of $16.5 \%$ partly improved boiler characteristics, while the recirculation of $33 \%$ did not, comparing with the case without recirculation.
\end{abstract}

Keywords: energy efficiency; mathematical models; non-linear regression; recirculation; wheat straw combustion 


\section{Introduction}

A great part of worldwide energy comes from fossil fuels such as oil derivatives, natural gas and coal. Because of the price increases of fossil fuel resources, their uncertain availability, and environmental concerns, the prediction is that oil exploitation will decrease in the near future. Because of that, total reliance on fossil fuels is not sustainable, and in order to make climate changes and pollution as small as possible, replacement of fossil fuels with biomass is necessary [1,2].

Serbia is a country poor in natural reserves of fossil fuels, hence its increased emphasis on direct use of renewable energy sources such as biomass, biogas, wind energy, solar energy, hydropower and geothermal energy [3]. Biomass has the greatest potential among renewable energy sources. Here, biomass refers to wood biomass and biomass which are the primary agricultural production and food industry residues.

In the face of a significant increase in population worldwide, it is necessary to produce more food to meet present and future demands. Therefore, use of agricultural products, including biomass, for energy purposes can be questionable. With that in mind, this research has been focused on the use of a secondary agricultural product (wheat straw) for energy purposes. Nevertheless, the implications of straw removal on the arable land is another point of discussion. The annual production of primary agricultural residues in Serbia is about $12.4 \times 10^{6} \mathrm{t}$. Research [4] has indicated that, without significant consequences in terms of compromising soil quality (crop plowing increases the humus content in soil and this results in an increase in soil quality), about a quarter of the produced biomass can be taken from the field and used for energy purposes. This means that, in Serbia, about $3.1 \times 10^{6} \mathrm{t}$ of biomass from agricultural production, which has a potential energy equivalence of $1 \times 10^{6} \mathrm{t}$ of fuel oil, can be used. The greatest biomass potential comes from corn and wheat and soybean straw. For this reason, research on the appropriate use of biomass for energy purposes have been performed in Serbia. This will significantly reduce the country's foreign trade deficit and increase profitability and quality of production.

For a comprehensive understanding of the techno-economic determinants of using wheat and soybean straw as a fuel, for selecting and designing the most appropriate technology, plant and equipment for its use of energy, it is necessary to have access to data concerning the thermo-physical and chemical properties of straw that are relevant to the specific conditions of exploitation [2].

Combustion characteristics of various biomass samples, such as sunflower shell, colza seed, pine cone, cotton refuse and olive refuse are given in [5]. Applying the derivative thermogravimetry technique, biomass materials showed different combustion characteristics. It should be mentioned that the combustion of the wheat straw can be divided into two stages. One is volatiles emission and combustion, the second is the residual volatiles and fixed carbon combustion [6].

Straw-fired boiler technology has been proven as an attractive method of disposing of agricultural residues for many years due to its primary advantages of $\mathrm{CO}_{2}$-neutrality [7], volume reduction [8] and energy recovery [9]. The combustion in an oxygen enriched air atmosphere has the following features: it reduces the available energy loss during the process of translating chemical energy into thermal energy; it decreases the concentration of organic pollutants in the exhaust gas; and it reduces the thermal energy of the exhaust gas to a minimum [10,11]. 
Research on biomass combustion on flat grids is widespread. Zhou et al. [12] examined the effect of air preheating and moisture level in the fuel on the combustion characteristics of corn straw. Mass loss rate as a function of time has similar properties as mass loss rate presented in this study. In [13] the authors presented the development of small-scale batch-fired straw boilers in Denmark in the period from 1995 to 2002 . The nominal boiler thermal power was 50-500 kW. One of the emphases was on improvements in boiler efficiency, which were primarily achieved by more installation inside the firebox, by improved techniques for the supply of secondary air and by lowering the flue gas temperature at the boiler outlet pipe. All measured values were recorded every ten seconds by a data logger. In this study, all measured values were recorded every 5 seconds. All stated values obtained during the combustion were averaged values measured throughout the entire combustion period like in this study. The minimum average boiler thermal power was $63 \mathrm{~kW}$, with an average efficiency of $75 \%$, while the maximum average boiler thermal power was $461 \mathrm{~kW}$ with an average efficiency of $88 \%$. In [14], the authors presented an experimental investigation into the combustion behavior of straw in a fixed bed combustor. Among others, they analyzed the effects of a crucial combustion parameter, primary air flow rate, on straw combustion. They reported that bale mass loss was the slowest at an air flow of $234 \mathrm{~kg} \mathrm{~m}^{-2} \mathrm{~h}^{-1}$ and that there was an exponential dependence of mass loss on bale residence time. The mass loss was the fastest at an air flow of $702 \mathrm{~kg} \mathrm{~m}^{-2} \mathrm{~h}^{-1}$, where a linear decrease occurred after the bed was ignited by the start-up burner.

Some research has included formulation of mathematical models. Zhou et al. [15], created a onedimensional unsteady heterogeneous mathematical model based on straw combustion in a fixed bed. A 3D mathematical model of straw combustion can be found in Zhaosheng et al. [16]. Combustion product composition (especially $\mathrm{CO}$ and $\mathrm{CO}_{2}$ ) was examined in Bubenheim et al. [17].

The goal of this study was to examine the influence of the quantity of inlet air and recirculation of combustion products on the boiler thermal power and boiler energy efficiency. Recirculation of combustion products of $\mathrm{p} \%$ means that out of $100 \%$ quantity of inlet air fed to the boiler firebox, $\mathrm{p} \%$ is warm air created from the combustion products and the rest is fresh air. Another aim is to formulate the equations which will represent the boiler thermal power and boiler energy efficiency dependence on wheat straw bale residence time.

\section{Material and Methods}

\subsection{Boiler Plant and Measurement Points}

This study describes a boiler plant for the combustion of wheat straw bales (Figure 1). The plant is located at the "Mitrosrem" agricultural company's "Kuzmin" working-unit in the town of Sremska

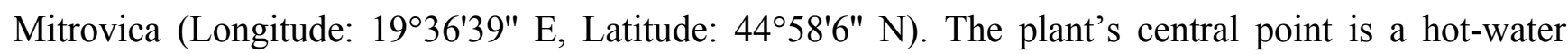
manually fed boiler with a nominal power of $120 \mathrm{~kW}$.

The boiler plant consists of several separate, but interconnected functional units which contain the necessary equipment for measurement and regulation. The functional units which make up the boiler plant are the following: supply pipe, measurement and regulation of the amount of fresh air which is fed into the firebox, combustion of bio-fuels and transfer of the produced thermal power, combustion products disposal and measurement and regulation equipment. 
Figure 1. Boiler plant of the "Ekoprodukt" manufacturer from Novi Sad with its measurement and regulation equipment (1-hot-water boiler, 2-combustion air fan, 3-tube for air supply into the combustion chamber, 4-airflow differential pressure meter with orifice plates (conic edge), 5-Pt100 temperature sensor for measuring air temperature, 6-sensor for measuring pressure of combustion air, 7-“U” tube, 8-differential pressure transmitters, 9-pressure transmitter, 10-ultrasonic water flowmeter, 11-Pt100 temperature sensor for measuring the temperature of output water, 12-sensor for measuring pressure of output water, 13-Pt100 temperature sensor for measuring the temperature of inlet water, 14-sensor for measuring pressure of incoming water, 15-flue gas analyzer, 16thermocouples for measuring flue gas temperature, type $\mathrm{K}$ ( $\mathrm{Ni}-\mathrm{CrNi}$ ), 17-sensor for measuring pressure of flue gas, 18-oxygen lambda sensor without heater, 19-oxygen lambda sensor with heater, 20-shut-off valve, 21-gate valve, 22-airflow differential pressure meter with orifice plates (conic edge), 23-Pt100 temperature sensor for measuring the temperature of flue gas recirculation, 24tube for intake of recirculation flue gas, 25-flue gas canal, 26-chimney, 27-frequency regulator for combustion air fan, 28-controller, 29-personal desktop computer, 30-expansion adapter EX-A1, 31-expansion module IOPT4, 32-expansion module IO-ATC8-, 33-expansion module IO-AI4-AO2, 34-tube of inlet water supply, 35-tube of output water).

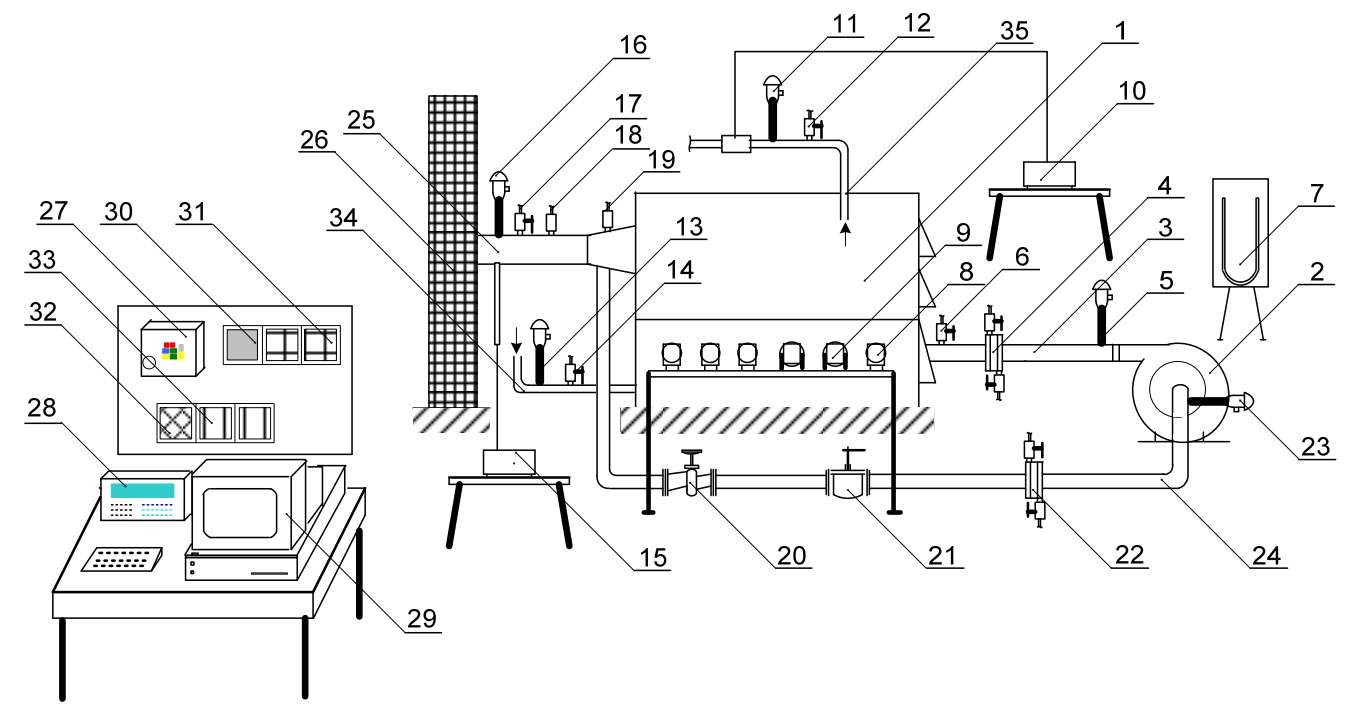

The tests were conducted during March and April 2011. The measurement results were automatically recorded in a controller every five seconds, thus enabling the continuous monitoring of the combustion process. Under the same circumstances, combustion of straw bales was repeated three times per each regime. Before we started with the experiments, we had carried out screening experiments to determine the time when the bale completely burnt out. We have visually determined that when the bale completely burnt out, the excess air ratio was about 7 . Therefore, combustion experiments were interrupted when the excess air ratio surpassed 7. Experimental measurements were conducted using the instruments given in Table 1. 
Table 1. Summary of measurement points and instruments.

\begin{tabular}{|c|c|c|c|c|c|}
\hline No. of meas. & Meas. design. & Measurement value & Type of instrument & $\begin{array}{l}\text { Meas. } \\
\text { range }\end{array}$ & $\begin{array}{c}\text { Meas. } \\
\text { accuracy and } \\
\text { resolution }\end{array}$ \\
\hline 1. & DB & Straw bale dimension & Strain gauge & - & - \\
\hline 2. & MB & Straw bale mass & "Labela-preciz" scale & $0-50 \mathrm{~kg}$ & $\pm 0.020 \mathrm{~kg}$ \\
\hline 3. & VS & $\begin{array}{l}\text { Straw humidity } \\
\text { contents }\end{array}$ & $\begin{array}{l}\text { Laboratory dryer and } \\
\text { "Sartorius" scale }\end{array}$ & $0-120 \mathrm{~g}$ & $\pm 0.001 \mathrm{~kg}$ \\
\hline 4. & TS & $\begin{array}{l}\text { Incineration time for } \\
\text { straw bale }\end{array}$ & Manual stopwatch & - & - \\
\hline 5. & TVL & $\begin{array}{c}\text { Firebox inlet air } \\
\text { temperature }\end{array}$ & $\begin{array}{l}\text { Temperature probe } \\
\text { type Pt-100 }\end{array}$ & $0-400{ }^{\circ} \mathrm{C}$ & $0.1^{\circ} \mathrm{C}$ \\
\hline 6. & TRG & $\begin{array}{l}\text { Temperature of the } \\
\text { recirculated } \\
\text { combustion products }\end{array}$ & $\begin{array}{l}\text { Temperature probe } \\
\text { type Pt-100 }\end{array}$ & $0-400{ }^{\circ} \mathrm{C}$ & $0.1^{\circ} \mathrm{C}$ \\
\hline 7. & TUV & $\begin{array}{l}\text { Boiler inlet water } \\
\text { temperature }\end{array}$ & $\begin{array}{l}\text { Temperature probe } \\
\text { type Pt-100 }\end{array}$ & $0-400{ }^{\circ} \mathrm{C}$ & $0.1^{\circ} \mathrm{C}$ \\
\hline 8. & TIV & $\begin{array}{l}\text { Boiler outlet water } \\
\text { temperature }\end{array}$ & $\begin{array}{c}\text { Temperature probe } \\
\text { type Pt-100 }\end{array}$ & $0-400{ }^{\circ} \mathrm{C}$ & $0.1^{\circ} \mathrm{C}$ \\
\hline 9. & TDG & Flue gas temperature & $\begin{array}{l}\text { Temperature probe } \\
\text { type } \mathrm{K}(\mathrm{Ni}-\mathrm{CrNi})\end{array}$ & $0-1200^{\circ} \mathrm{C}$ & $0.1^{\circ} \mathrm{C}$ \\
\hline 10. & $\mathrm{TO}$ & $\begin{array}{l}\text { Environment } \\
\text { temperature }\end{array}$ & $\begin{array}{c}\text { Republic of Serbia } \\
\text { hydrometeorological } \\
\text { service }\end{array}$ & - & $0.1^{\circ} \mathrm{C}$ \\
\hline 11. & TOK & $\begin{array}{l}\text { Environment } \\
\text { temperature }\end{array}$ & $\begin{array}{l}\text { Temperature probe } \\
\text { type Pt-100 }\end{array}$ & $0-400{ }^{\circ} \mathrm{C}$ & $0.1^{\circ} \mathrm{C}$ \\
\hline 12. & VV & $\begin{array}{l}\text { Environment } \\
\text { humidity }\end{array}$ & $\begin{array}{c}\text { Republic of Serbia } \\
\text { hydrometeorological } \\
\text { service }\end{array}$ & - & - \\
\hline 13. & $\mathrm{PO}$ & $\begin{array}{l}\text { Environment } \\
\text { air-pressure }\end{array}$ & $\begin{array}{c}\text { Republic of Serbia } \\
\text { hydrometeorological } \\
\text { service }\end{array}$ & - & $0.1 \mathrm{mbar}$ \\
\hline 14. & BV & Wind speed & $\begin{array}{c}\text { Republic of Serbia } \\
\text { hydrometeorological } \\
\text { service }\end{array}$ & - & - \\
\hline 15. & PUV & $\begin{array}{l}\text { Boiler inlet water } \\
\text { pressure }\end{array}$ & $\begin{array}{l}\text { Pressure transmitter } \\
\text { type SITRANS DSIII }\end{array}$ & $0-10$ bar & $0.1 \mathrm{mbar}$ \\
\hline 16. & PIV & $\begin{array}{l}\text { Boiler outlet water } \\
\text { temperature }\end{array}$ & $\begin{array}{l}\text { Pressure transmitter } \\
\text { type SITRANS DSIII }\end{array}$ & 0-10 bar & $0.1 \mathrm{mbar}$ \\
\hline 17. & PVL & $\begin{array}{l}\text { Firebox inlet air } \\
\text { pressure }\end{array}$ & $\begin{array}{l}\text { SITRANS DSIII } \\
\text { differential pressure } \\
\text { transmitter }\end{array}$ & $\begin{array}{c}0-1600 \\
\text { mbar }\end{array}$ & $0.1 \mathrm{mbar}$ \\
\hline 18. & PRG & $\begin{array}{c}\text { Combustion products } \\
\text { pressure }\end{array}$ & $\begin{array}{l}\text { SITRANS DSIII } \\
\text { differential pressure } \\
\text { transmitter }\end{array}$ & $\begin{array}{l}0-1600 \\
\text { mbar }\end{array}$ & $0.1 \mathrm{mbar}$ \\
\hline
\end{tabular}


Table 1. Cont.

\begin{tabular}{|c|c|c|c|c|c|}
\hline No. of meas. & Meas. design. & Measurement value & Type of instrument & $\begin{array}{l}\text { Meas. } \\
\text { range }\end{array}$ & $\begin{array}{c}\text { Meas. } \\
\text { accuracy and } \\
\text { resolution } \\
\end{array}$ \\
\hline 19. & PRV & $\begin{array}{l}\text { Firebox inlet air } \\
\text { throughput }\end{array}$ & $\begin{array}{c}\text { Standard muffler and } \\
\text { SITRANS DSIII } \\
\text { differential pressure } \\
\text { transmitter }\end{array}$ & $\begin{array}{c}0-1600 \\
\text { mbar }\end{array}$ & $0.1 \mathrm{mbar}$ \\
\hline 20. & PRG & $\begin{array}{c}\text { Recirculated } \\
\text { combustion products } \\
\text { throughput }\end{array}$ & $\begin{array}{l}\text { Standard muffler and } \\
\text { SITRANS DSIII } \\
\text { differential pressure } \\
\text { transmitter }\end{array}$ & $\begin{array}{c}0-1600 \\
\text { mbar }\end{array}$ & $0.1 \mathrm{mbar}$ \\
\hline 21. & PV & $\begin{array}{c}\text { Boiler water } \\
\text { throughput }\end{array}$ & $\begin{array}{l}\text { Yokogawa type } \\
\text { US300PM ultrasound } \\
\text { throughput probe }\end{array}$ & & \\
\hline 22. & KVV & Air excess rate 1 & $\begin{array}{l}\text { Universal lambda } \\
\text { probe Bosch LS } 01\end{array}$ & $0-1.1 \mathrm{~V}$ & $0.01 \mathrm{~V}$ \\
\hline 23. & KVV & Air excess rate 2 & $\begin{array}{l}\text { Universal lambda } \\
\text { probe with heater } \\
\text { Bosch LS } 01\end{array}$ & $0-1.1 \mathrm{~V}$ & $0.01 \mathrm{~V}$ \\
\hline 24. & SK & $\begin{array}{c}\mathrm{O}_{2} \text { content in } \\
\text { combustion products }\end{array}$ & $\begin{array}{c}\text { TESTO } 350 \mathrm{XL} \\
\text { combustion analyser }\end{array}$ & $0-21 \%$ & - \\
\hline 25. & SUD & $\begin{array}{l}\mathrm{CO}_{2} \text { content in } \\
\text { combustion products }\end{array}$ & $\begin{array}{c}\text { TESTO } 350 \mathrm{XL} \\
\text { combustion analyser }\end{array}$ & $0-20.5 \%$ & $0.2 \%$ \\
\hline 26. & SUM & $\begin{array}{c}\text { CO content in } \\
\text { combustion products }\end{array}$ & $\begin{array}{c}\text { TESTO } 350 \mathrm{XL} \\
\text { combustion analyser }\end{array}$ & $\begin{array}{c}0-10,000 \\
\text { ppm }\end{array}$ & $1 \mathrm{ppm}$ \\
\hline 27. & KPS & $\begin{array}{l}\text { Air excess rate in } \\
\text { combustion products }\end{array}$ & $\begin{array}{c}\text { TESTO } 350 \mathrm{XL} \\
\text { combustion analyser }\end{array}$ & - & - \\
\hline 28. & SAX & $\begin{array}{c}\mathrm{NO}_{\mathrm{x}} \text { content in } \\
\text { combustion products }\end{array}$ & $\begin{array}{c}\text { TESTO } 350 \mathrm{XL} \\
\text { combustion analyser }\end{array}$ & - & - \\
\hline 29. & SAM & $\begin{array}{c}\text { NO content in } \\
\text { combustion products }\end{array}$ & $\begin{array}{c}\text { TESTO } 350 \mathrm{XL} \\
\text { combustion analyser }\end{array}$ & $\begin{array}{c}0-3000 \\
\text { ppm }\end{array}$ & $1 \mathrm{ppm}$ \\
\hline 30. & SAD & $\begin{array}{c}\mathrm{NO}_{2} \text { content in } \\
\text { combustion products }\end{array}$ & $\begin{array}{c}\text { TESTO } 350 \mathrm{XL} \\
\text { combustion analyser }\end{array}$ & $\begin{array}{l}0-500 \\
\mathrm{ppm}\end{array}$ & $0.1 \mathrm{ppm}$ \\
\hline 31. & SSD & $\begin{array}{c}\mathrm{SO}_{2} \text { content in } \\
\text { combustion products }\end{array}$ & $\begin{array}{c}\text { TESTO } 350 \mathrm{XL} \\
\text { combustion analyser }\end{array}$ & $\begin{array}{c}0-5000 \\
\text { ppm }\end{array}$ & $1 \mathrm{ppm}$ \\
\hline 32. & SKK & $\begin{array}{c}\text { Efficiency in } \\
\text { combustion products }\end{array}$ & $\begin{array}{c}\text { TESTO } 350 \mathrm{XL} \\
\text { combustion analyser }\end{array}$ & - & - \\
\hline 33. & SV & $\begin{array}{c}\mathrm{H}_{2} \text { content in } \\
\text { combustion products }\end{array}$ & $\begin{array}{c}\text { TESTO } 350 \mathrm{XL} \\
\text { combustion analyser }\end{array}$ & - & - \\
\hline
\end{tabular}

Locations where measurements were taken are shown in Figure 2. Measured values are marked according to their labels listed in Table 1. 
Figure 2. Layout of measurement points.

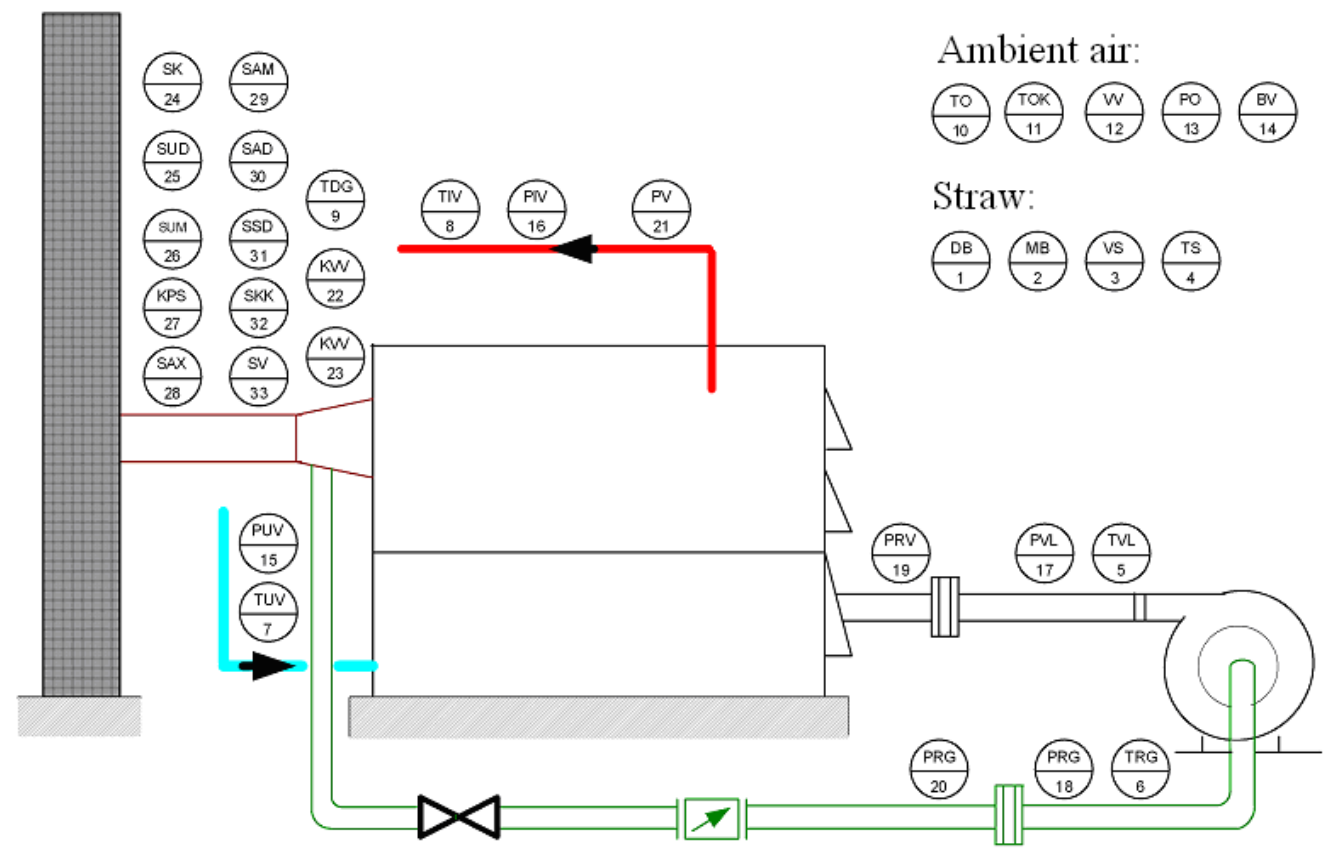

\subsection{Wheat Straw Characteristics}

For the purpose of this study, prismatic wheat straw bales were used. The straw collection was conducted right after the harvest. The straw was baled with a press, and stored in piles in the agricultural courtyards of the working-unit. In laboratory terms, the average heating value of wheat straw was $13.48 \mathrm{MJ} \mathrm{kg}^{-1}$ (moisture content $8.2 \%$ ). After drying, it was $14.9 \mathrm{MJ} \mathrm{kg}^{-1}$. In laboratory terms the average value of the quantity of wheat straw ashes was $6.2 \%$ [18]. Composition of wheat straw biomass from Serbia is given in Table 2 [19].

Table 2. Chemical composition of wheat straw from Serbia.

\begin{tabular}{lrlr}
\hline & Content & & \multicolumn{1}{c}{ Content } \\
\hline Ash & $7.9 \%$ & Aluminum & $240 \mathrm{mg} \mathrm{kg}^{-1}$ \\
Carbon & $42.9 \%$ & Calcium & $1720 \mathrm{mg} \mathrm{kg}^{-1}$ \\
Chlorine & $0.17 \%$ & Iron & $240 \mathrm{mg} \mathrm{kg}^{-1}$ \\
Hydrogen & $5.7 \%$ & Magnesium & $620 \mathrm{mg} \mathrm{kg}^{-1}$ \\
Nitrogen & $0.62 \%$ & Manganese & $40 \mathrm{mg} \mathrm{kg}^{-1}$ \\
Oxygen & $38.25 \%$ & Phosphorus & $700 \mathrm{mg} \mathrm{kg}^{-1}$ \\
Sulfur & $0.16 \%$ & Potassium & $10,440 \mathrm{mg} \mathrm{kg}^{-1}$ \\
Water & $4.3 \%$ & Silicon & $34,090 \mathrm{mg} \mathrm{kg}^{-1}$ \\
\hline
\end{tabular}

Bales of approximately the same size and weight were selected. Upon selection they were stored in the warehouse of the "Kuzmin" working-unit. Altogether, 350 wheat straw bales were selected. They were stored in a warehouse near the boiler plant so they were not exposed to additional climate effects, which helped in preserving their quality and prevented deterioration of the content, shape and the level of compactness. The average cross-cut of the wheat bales was $0.35 \mathrm{~m} \times 0.5 \mathrm{~m}$, whereas the average length was $0.75 \mathrm{~m}$. The compactness was rather equal. During each experiment, one wheat straw bale was burnt. 


\subsection{Operating Regimes}

This study shows different boiler operating regimes (the amount of air fed into a boiler varied). The effects of four different operating regimes $\left(220,290,360\right.$ and $\left.430 \mathrm{~m}^{3} \mathrm{~h}^{-1}\right)$ on the combustion process are described. The amount of air fed into the firebox during the combustion process influences on the energy efficiency rate of the boiler that runs on biomass. Measurement methods are in accordance with the SRPS EN 303-5:2007 standards and DIN 4702 in boiler thermal power determination. Boiler thermal power was determined using a direct method [18], i.e., by measuring the volume of water supplied and by measuring the water temperature at the boiler entrance and exit points. A detailed overview (measuring codes, bale dimensions, instrument names, measuring ratio) is also given in $[20,21]$. During the experiments, boiler thermal power was determined based on the following formula [22]:

$$
P=\dot{m}_{v} \cdot c_{p} \cdot\left(t_{i v}-t_{u v}\right)
$$

where $P$ is the boiler thermal power, $\dot{m}_{v}$ mass flow of water through the boiler $\left(\mathrm{m}^{3} \mathrm{~h}^{-1}\right), c_{p}$ specific heat of water, $t_{i v}$ boiler outlet water temperature, $t_{u v}$ boiler inlet water temperature. Energy efficiency rate of a boiler was determined by [22]:

$$
\eta(\tau)=\frac{P \cdot c_{p} \cdot\left(t_{i v}-t_{u v}\right)}{\left(m_{0}-m(\tau)\right) \cdot h_{d}}
$$

where $\eta(\tau)$ is energy efficiency rate, $P$ is the boiler thermal power, $m_{0}$-bale mass $(\mathrm{kg}), m(\tau)$-bale mass at time $\tau(\mathrm{kg}), h_{d}$ heating value of fuel $\left(\mathrm{kJ} \mathrm{kg}^{-1}\right), t_{i v}$ boiler outlet water temperature, $t_{u v}$ boiler inlet water temperature.

\subsection{Statistical Analysis}

Mathematical models were obtained from experimental data and application of nonlinear regression analysis. Regression analysis comprises the following: the choice of appropriate regression function $f\left(x_{1}, x_{2}, \ldots\right)=\varphi\left(\beta_{1}, \beta_{2}, \ldots, x_{1}, x_{2}, \ldots\right)$, where $\beta_{1}, \beta_{2}, \ldots$ are regression coefficients, and $x_{1}, x_{2}, \ldots$ are independent variables; evaluation of regression coefficients $\beta_{1}, \beta_{2}, \ldots$, that is, determining their approximate values $b_{1}, b_{2}, \ldots$ in order for the function $\varphi\left(b_{1}, b_{2}, \ldots, x_{1}, x_{2}, \ldots\right)$ to represent as close as possible approximation of regression function $f\left(x_{1}, x_{2}, \ldots\right)$. Coefficients $b_{1}, b_{2}, \ldots$ are called empirical regression coefficients; statistical analysis of the obtained approximation (precision in prediction, regression coefficient intervals, etc.).

The compatibility of mathematical models with the measured data is checked with the following tests: $t$-test examines the regression coefficients' significance, $F$-test determines the significance of factors effects on dependent variables, i.e., whether the set model is significant, the level of determination of dependent variables is shown through the coefficient of determination $R^{2}$ for the chosen independent variables and it shows the compatibility of the curves to the results [23].

This study contains the following mathematical models and formulas: correlation between boiler thermal power and bale residence time; correlation between boiler energy efficiency and bale residence time; bale mass loss during the combustion process. These models are presented for all regimes and all types of combustion products recirculation. 


\section{Results and Discussion}

This research shows the mathematical models resulting from the average values of combustion parameter experiments (boiler thermal power and boiler energy efficiency) repeated three times at every operating regime with $0,16.5$ and $33 \%$ recirculation. The average time when bale totally burnt, as well as the average values of boiler thermal power and energy efficiency rate, during the whole combustion process are presented in Table 3. Intervals of standard error of average boiler thermal power and energy efficiency in percentages are also presented.

Table 3. Combustion process results with intervals of standard error in percentages.

\begin{tabular}{lccccc}
\hline & \multirow{2}{*}{ Rec. } & \multicolumn{4}{c}{ Boiler operating regime $\left.\mathbf{~ m}^{\mathbf{3}} \mathbf{h}^{-\mathbf{1}}\right)$} \\
\cline { 3 - 7 } & & $\mathbf{2 2 0}$ & $\mathbf{2 9 0}$ & $\mathbf{3 6 0}$ & $\mathbf{4 3 0}$ \\
\hline Average time when bale & $0 \%$ & $1055(6.58)$ & $947(0.88)$ & $650(2.80)$ & $587(2.50)$ \\
totally burnt (s) with & $16.5 \%$ & $1427(5.06)$ & $1312(2.73)$ & $772(4.67)$ & $698(4.00)$ \\
standard error (\%) & $33 \%$ & $1185(6.04)$ & $955(3.42)$ & $710(2.09)$ & $632(2.80)$ \\
\hline Average boiler thermal & $0 \%$ & $63.47(0.27,12.15)$ & $71.75(0.73,11.44)$ & $88.21(0.44,13.36)$ & $90.90(1.05,12.76)$ \\
power (kW) with intervals & $16.5 \%$ & $57.86(0.40,10.22)$ & $68.88(1.38,11.69)$ & $81.44(0.17,10.08)$ & $88.12(0.42,9.03)$ \\
of standard error (\%) & $33 \%$ & $55.65(0.35,12.45)$ & $67.79(0.27,6.31)$ & $72.82(0.91,10.12)$ & $84.98(0.25,4.90)$ \\
\hline Average boiler energy & $0 \%$ & $57.94(0.03,12.89)$ & $60.00(1.08,11.08)$ & $39.45(1.05,12.76)$ & $36.57(0.08,12.47)$ \\
efficiency rate (\%) with & $16.5 \%$ & $66.08(0.14,11.33)$ & $52.83(0.20,13.73)$ & $45.50(1.01,9.39)$ & $42.60(0.29,8.45)$ \\
intervals of st. error (\%) & $33 \%$ & $49.85(0.59,11.46)$ & $41.64(0.24,5.63)$ & $44.01(1.84,10.26)$ & $41.77(0.57,7.15)$ \\
\hline
\end{tabular}

General conclusions are: (1) increase of inlet air fed to the boiler firebox produces a combustion time decrease and an increase of boiler thermal power; (2) combustion product recirculation increases bale residence time and decreases average boiler thermal power; (3) in the 220 and $290 \mathrm{~m}^{3} \mathrm{~h}^{-1}$ regimes average boiler energy efficiency is greater than $50 \%$ if recirculation is 0 or $16.5 \%$; (4) in the 360 and $430 \mathrm{~m}^{3} \mathrm{~h}^{-1}$ regimes average boiler energy efficiency is very small; (5) maximum average boiler energy efficiency $(66.08 \%)$ is reached in the $220 \mathrm{~m}^{3} \mathrm{~h}^{-1}$ regime if recirculation is $16.5 \%$ and after that $(60 \%)$ in the $290 \mathrm{~m}^{3} \mathrm{~h}^{-1}$ regime if there is no recirculation; (6) in the 360 and $430 \mathrm{~m}^{3} \mathrm{~h}^{-1}$ regimes with 16.5 and $33 \%$ recirculation average boiler energy efficiency is increased compared to the efficiency when there is no recirculation. This is due to a relatively small change in boiler thermal power and higher bale residence time; (7) comparing recirculation of 16.5 and $33 \%$, it can be seen that first one provides better boiler characteristics regarding all considered parameters.

\subsection{Boiler Thermal Power-Experimental Data and Mathematical Model}

Our first task was to express boiler thermal power as a function of air flow and bale residence time. Therefore, according to Figure 3(a), it can be concluded that for higher air flow (360 and $\left.430 \mathrm{~m}^{3} \mathrm{~h}^{-1}\right)$, experimental data should be approximated by an exponential function $\exp \left(-(x-a)^{2}\right)$ which is symmetric with respect to the line $x=a$ and its graphical interpretation fits a normal distribution ( $a$ serves for graph translation along the $x$-axis). One can see that: (a) higher air flow $\dot{v}$ implies higher maximum boiler thermal power $P$ (so the regression coefficients $b$ and $\dot{v}$ should multiply the function $\exp \left(-(x-a)^{2}\right)$ and we obtain $b \cdot \dot{v} \cdot \exp \left(-(x-a)^{2}\right)$; (b) higher air flow $\dot{v}$ makes the time $\tau_{k r}$ when the bale is totally burnt shorter and the graph becomes narrower. Thus, function $b \cdot \dot{v} \cdot \exp \left(-\left(c(x-a) / \tau_{k r}\right)^{2}\right)$ 
should properly approximate the experimental data for higher regimes. Regression coefficients $a, b$ and $c$ are useful for graph corrections according to experimental data. For lower air flows (220 and $\left.290 \mathrm{~m}^{3} \mathrm{~h}^{-1}\right)$, experimental data should be approximated by a function of the type $\dot{v} \cdot \sin \left((x-b) / \tau_{k r}\right)$, with the same arguments as stated above. Finally, a mathematical model of the correlation between boiler thermal power and bale residence time for different operating regimes is formed on the basis of the model in [3] and it is given in (1):

$$
P\left(\tau, \tau_{k r}, \dot{v}\right)=b_{1}+b_{2} \cdot \dot{v} \cdot \exp \left(-\left(b_{3} \cdot \frac{\left(\tau-b_{4}\right)}{\tau_{k r}}\right)^{2}\right)+b_{5} \cdot \dot{v} \cdot \sin \left(b_{6} \cdot \frac{\left(\tau-b_{7}\right)}{\tau_{k r}}\right)
$$

Here, $b_{1}, b_{2}, \ldots, b_{7}$ are regression coefficients given in Table $4 \mathrm{a}, 4 \mathrm{~b}$ and $4 \mathrm{c}, \tau$ is the bale residence time, $P$ is the boiler thermal power, $\dot{v}$ is air flow and $\tau_{k r}$ is the time when the bales are totally burnt.

Table 4. Estimation of empirical regression coefficients and analysis of variance of model (1), (a) no recirculation; (b) recirculation 16.5\%; (c) recirculation 33\%.

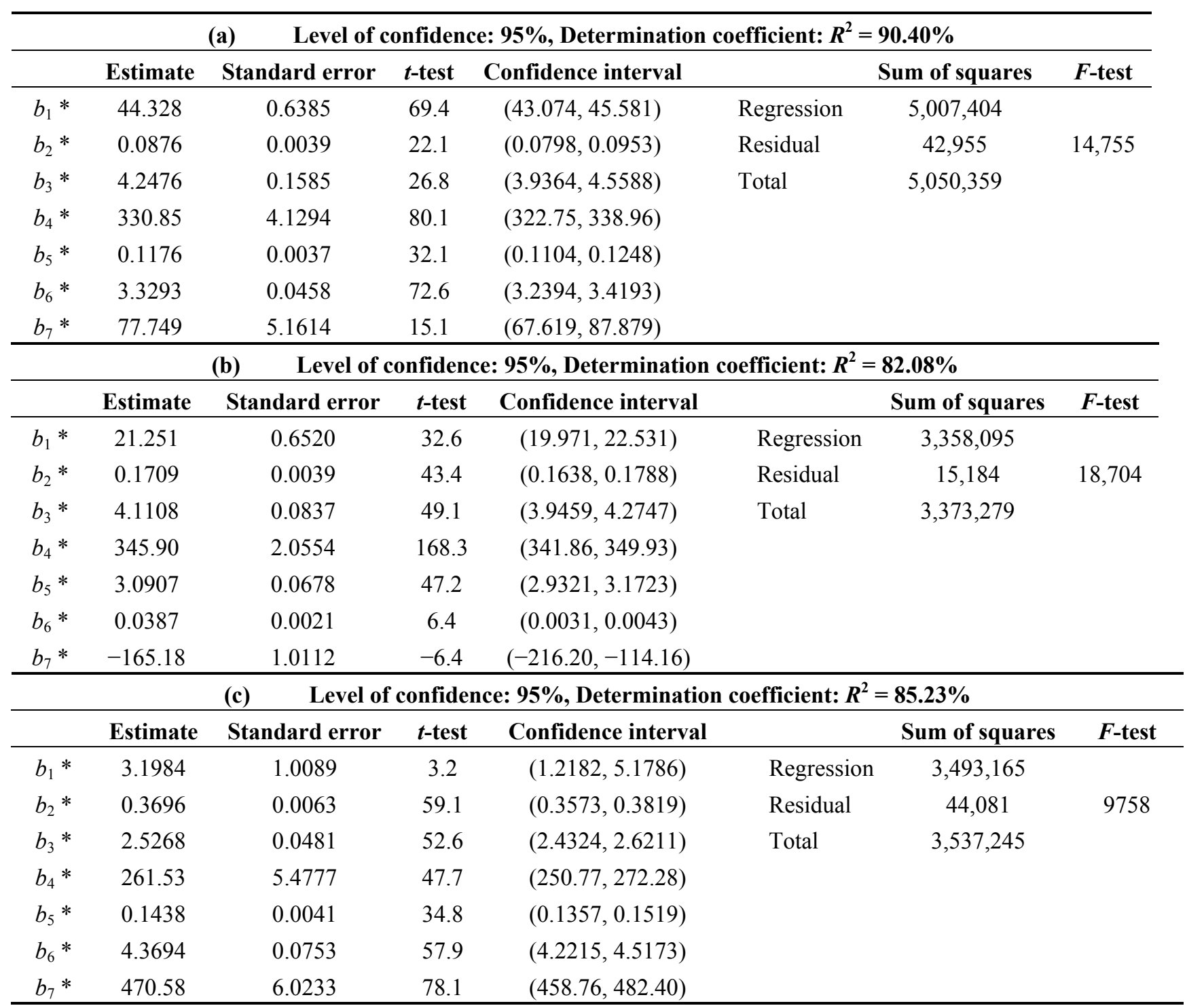

\footnotetext{
* significant coefficients at significance level of $P<0.05$.
} 
Experimental data of boiler thermal power and its graphical interpretation based on formula (1) are given in Figure 3(a) and 3(b) (for the case of recirculation $0 \%$ ). If there is no combustion products recirculation into the firebox, then two operating regimes can be regarded as the optimal ones (220 and $290 \mathrm{~m}^{3} \mathrm{~h}^{-1}$ ) regarding to boiler thermal power values and time when bale totally burnt. At the operating regime $220 \mathrm{~m}^{3} \mathrm{~h}^{-1}$, the maximum boiler thermal power was $84.05 \mathrm{~kW}$ with $\tau_{k r}=1055 \mathrm{~s}$. At the operating regime $290 \mathrm{~m}^{3} \mathrm{~h}^{-1}$, the maximum boiler thermal power was $97.97 \mathrm{~kW}$ and $\tau_{k r}=947 \mathrm{~s}$.

Figure 3. (a) Correlation between boiler thermal power and bale residence time, experimental data, recirculation $0 \%$; (b) Correlation between boiler thermal power and bale residence time, model (1), recirculation $0 \%$.
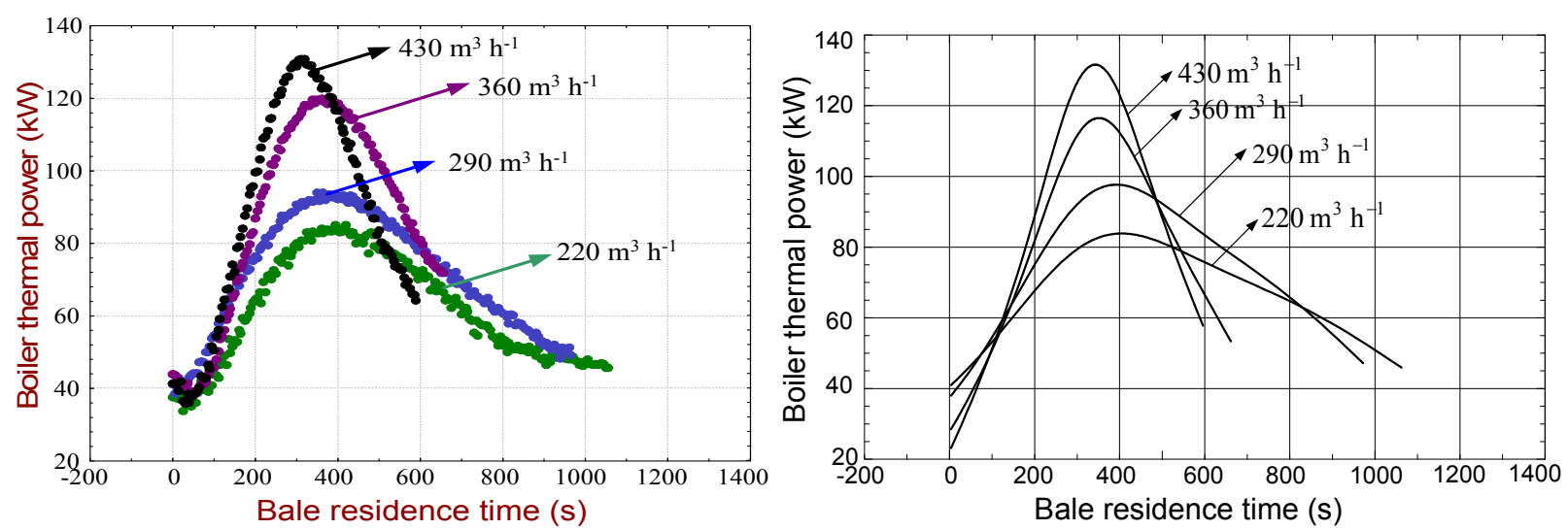

Graphical interpretation for two other recirculation types can be seen in Figures 4 and 5 . If the combustion products recirculation of $16.5 \%$ (or $33 \%$ ) occurs, then the time when bale was totally burnt was prolonged, but the average thermal boiler power was smaller compared to the case when recirculation is $0 \%$ (Table 3 ).

Figure 4. Correlation between boiler thermal power and bale residence time, model (1), recirculation $16.5 \%$.

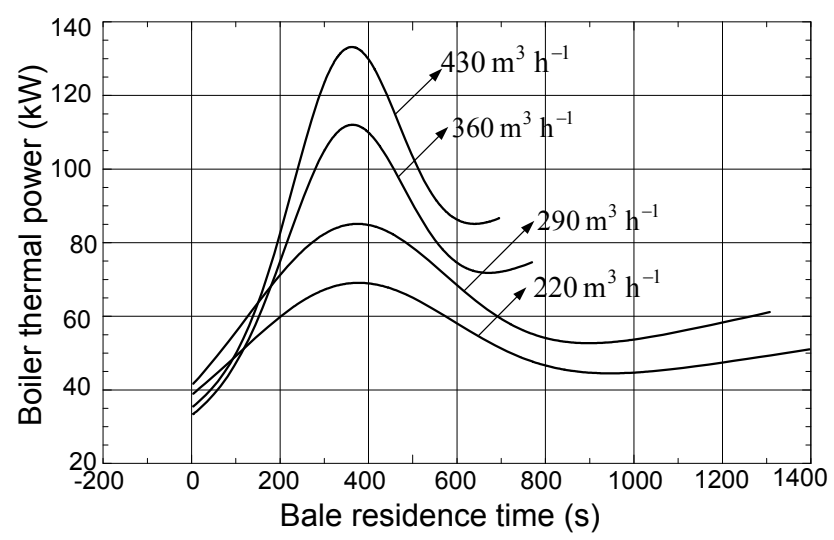


Figure 5. Correlation between boiler thermal power and bale residence time, model (1), recirculation $33 \%$.

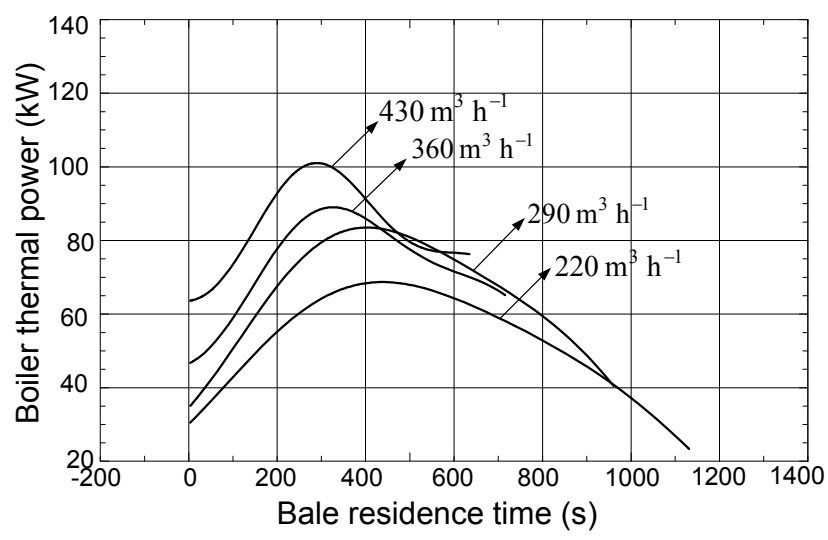

\subsection{Mass Decreasing-Mathematical Model}

During boiler plants exploitation, it is well known that higher boiler thermal power reduces the energy efficiency [1]. For this reason it is necessary, along with measuring the boiler thermal power, to measure boiler energy efficiency rate. The natural assumption is that percentage of bale mass loss is equal to percentage of $\mathrm{CO}_{2}$ decrease during the combustion process [22]. Based on experimental data [22] (obtained by a Testo 350XL combustion analyzer), the dependence of the amount of $\mathrm{CO}_{2}$ on bale residence time $\tau$ can be written as:

$$
\mathrm{CO}_{2}(\tau)=b_{1} \cdot e^{-b_{2} \cdot \tau}
$$

where $b_{1}$ and $b_{2}$ are regression coefficients obtained by nonlinear regression analysis (estimation of empirical regression coefficients for all regimes and all types of recirculation are also given in [22]). Note that $b_{1}=\mathrm{CO}_{2}(0)$. Percentage change of $\mathrm{CO}_{2}$ is equal to:

$$
\Delta \mathrm{CO}_{2}(\tau)=\frac{b_{1}-b_{1} \cdot e^{-b_{2} \cdot \tau}}{b_{1}} \cdot 100
$$

or $\Delta \mathrm{CO}_{2}(\tau)=\left(1-e^{-b_{2} \cdot \tau}\right) \cdot 100$. The main assumption here is that the percentage change of bale mass is equal to $\left(1-e^{-b_{2} \cdot \tau}\right) \cdot 100$. Therefore, the equation for mass decrease should be $m(\tau)=m_{0} \cdot e^{-b_{2} \cdot \tau}$ since:

$$
\Delta m(\tau)=\frac{m_{0}-m_{0} e^{-b_{2} \cdot \tau}}{m_{0}} \cdot 100=\frac{m_{0}\left(1-e^{-b_{2} \cdot \tau}\right)}{m_{0}} \cdot 100=\left(1-e^{-b_{2} \cdot \tau}\right) \cdot 100
$$

Exponential dependence was also confirmed by Janić [3]. Figures 6 to 8 presented graphs of mass loss during the combustion process for each type of regime and recirculation. Furthermore, there are given formulas by which these graphics have been obtained. In Formulas (2-4) unburned bale mass at time $\tau$ for all regimes and all recirculation types is given. In (2-4), $\tau$ is the bale residence time, $m_{0}$ is bale weight, $\Delta m$ is a change in bale weight over time. 
Figure 6. Mass loss rate as a function of time, recirculation $0 \%$.

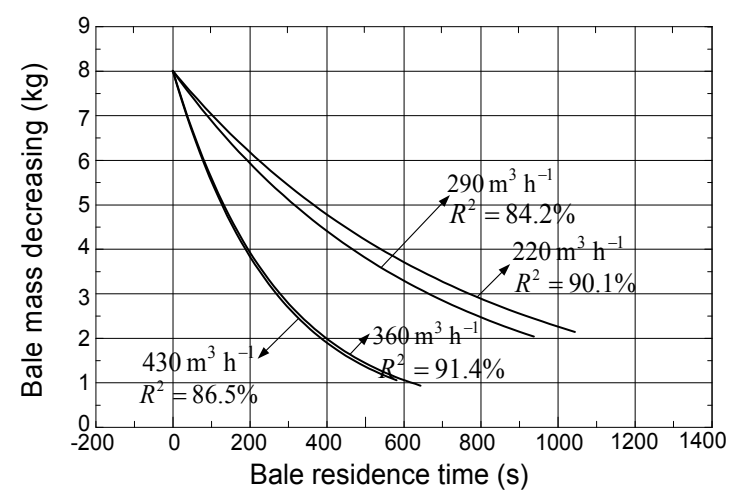

$$
\begin{aligned}
& \Delta m\left(\tau, 220, m_{0}\right)=m_{0}-m_{0} \exp (-0,00132 \cdot \tau) \\
& \Delta m\left(\tau, 290, m_{0}\right)=m_{0}-m_{0} \exp (-0,00153 \cdot \tau) \\
& \Delta m\left(\tau, 360, m_{0}\right)=m_{0}-m_{0} \exp (-0,00365 \cdot \tau) \\
& \Delta m\left(\tau, 430, m_{0}\right)=m_{0}-m_{0} \exp (-0,00378 \cdot \tau)
\end{aligned}
$$

Figure 7. Mass loss rate as a function of time, recirculation $16.5 \%$.

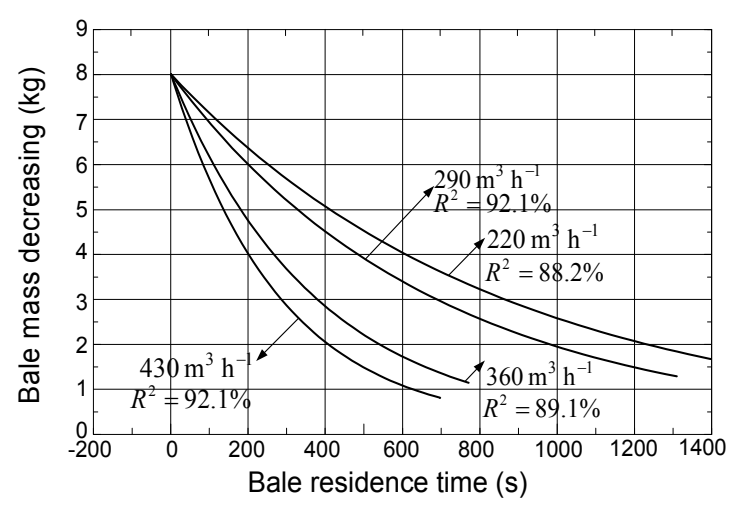

$$
\begin{aligned}
& \Delta m\left(\tau, 220, m_{0}\right)=m_{0}-m_{0} \exp (-0,00117 \cdot \tau) \\
& \Delta m\left(\tau, 290, m_{0}\right)=m_{0}-m_{0} \exp (-0,00147 \cdot \tau) \\
& \Delta m\left(\tau, 360, m_{0}\right)=m_{0}-m_{0} \exp (-0,00267 \cdot \tau) \\
& \Delta m\left(\tau, 430, m_{0}\right)=m_{0}-m_{0} \exp (-0,00354 \cdot \tau)
\end{aligned}
$$

Figure 8. Mass loss rate as a function of time, recirculation $33 \%$.

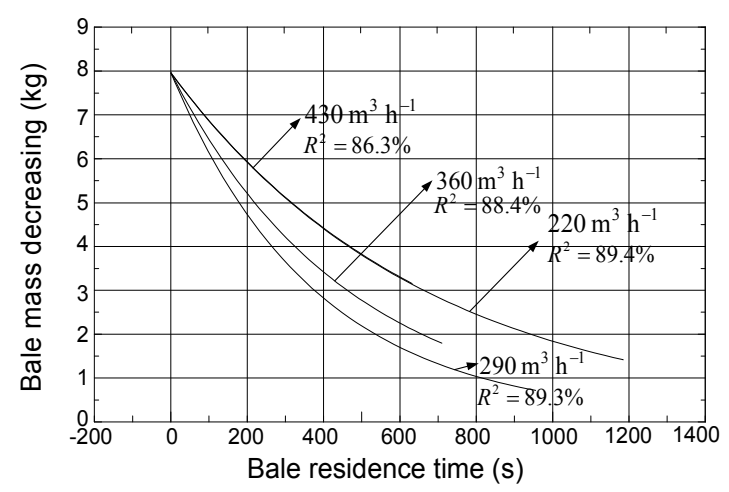

$$
\begin{aligned}
& \Delta m\left(\tau, 220, m_{0}\right)=m_{0}-m_{0} \exp (-0,00150 \cdot \tau) \\
& \Delta m\left(\tau, 290, m_{0}\right)=m_{0}-m_{0} \exp (-0,00264 \cdot \tau) \\
& \Delta m\left(\tau, 360, m_{0}\right)=m_{0}-m_{0} \exp (-0,00215 \cdot \tau) \\
& \Delta m\left(\tau, 430, m_{0}\right)=m_{0}-m_{0} \exp (-0,00149 \cdot \tau)
\end{aligned}
$$

If the recirculation is 0 and $16.5 \%$ (Figures 6 and 7), in the 220 and $290 \mathrm{~m}^{3} \mathrm{~h}^{-1}$ regimes, bale mass loss is slower, while the time when bale totally burnt is almost twice as long as in the 360 and $430 \mathrm{~m}^{3} \mathrm{~h}^{-1}$ regimes. These make the 220 and $290 \mathrm{~m}^{3} \mathrm{~h}^{-1}$ regimes acceptable for further research. If the recirculation of combustion products is $33 \%$ (Figure 8), then bale mass loss is the fastest in the $290 \mathrm{~m}^{3} \mathrm{~h}^{-1}$ regime, and the slowest in the $430 \mathrm{~m}^{3} \mathrm{~h}^{-1}$ regime, probably due to an insufficient amount of oxygen. More precisely, disturbance of combustion regimes, due to injection of excessive amounts of air, has been confirmed in several independent studies $[3,22,24]$. Good combustion requires three preconditions to be satisfied: the presence of the fuel components, mixing with the oxygen fuel components, and heat of activation of the combustion process. Combustion processes in higher operating regimes lead to fast decomposition, so called "dry distillation", of wheat bales, which suggests that a firebox contains a 
large amount of combustible components. When the firebox contains substantial amounts of air, then it contains more than enough oxygen for the realization of the combustion process, implying that third basic condition for combustion is not satisfied. This implies the heat of activation of the combustion process is reduced. Large quantities of air, which are inserted in the $430 \mathrm{~m}^{3} \mathrm{~h}^{-1}$ regime, cool the inside of the firebox and large amounts of heat are removed from the boiler firebox, which further disrupts the combustion process, i.e., combustion rate decreases. This regime has been picked for a purpose. It serves to certify researches conducted in [3]. This result is very important, since it clearly points out that, in practice, we cannot count on unlimited power increases of the boiler thermal power due to the addition of air.

\subsection{Boiler Energy Efficiency-Experimental Data and Mathematical Model}

It is well known that boiler energy efficiency is directly proportional to boiler thermal power and inversely proportional to mass loss. Defining mass loss as a function of bale residence time, allows us to present the boiler energy efficiency rate dependence on bale residence time. The mathematical models which describe those correlations are given in $(5 \mathrm{a}-\mathrm{c})$ in case of no recirculation, and combustion products recirculation of 16.5 and $33 \%$, respectively.

$\eta\left(\tau, \tau_{k r}, \dot{v}, \Delta m\right)=\frac{b_{8} \cdot \tau \cdot\left(\mathrm{b}_{9}+0.0876 \cdot \dot{v} \cdot \exp \left(-\left(4.2476 \cdot \frac{(\tau-330.85)}{\tau_{k r}}\right)^{2}\right)+0.1176 \cdot \dot{v} \cdot \sin \left(3.3293 \cdot \frac{(\tau-77.749)}{\tau_{k r}}\right)\right)}{\Delta m\left(\tau, \dot{v}, m_{0}\right)}$

$\eta\left(\tau, \tau_{k r}, \dot{v}, \Delta m\right)=\frac{b_{8} \cdot \tau \cdot\left(b_{9}+0.171 \cdot \dot{v} \cdot \exp \left(-\left(4.111 \cdot \frac{(\tau-345.898)}{\tau_{k r}}\right)^{2}\right)+3.091 \cdot \dot{v} \cdot \sin \left(0.039 \cdot \frac{(\tau+165.180)}{\tau_{k r}}\right)\right)}{\Delta m\left(\tau, \dot{v}, m_{0}\right)}$

$\eta\left(\tau, \tau_{k r}, \dot{v}, \Delta m\right)=\frac{b_{8} \cdot \tau \cdot\left(b_{9}+0.3696 \cdot \dot{v} \cdot \exp \left(-\left(2.5268 \cdot \frac{(\tau-261.5257)}{\tau_{k r}}\right)^{2}\right)+0.1438 \cdot \dot{v} \cdot \sin \left(4.3694 \cdot \frac{(\tau-470.582)}{\tau_{k r}}\right)\right)}{\Delta m\left(\tau, \dot{v}, m_{0}\right)}$

Here, $b_{8}$ and $b_{9}$ are the regression coefficients shown in Tables $5 \mathrm{a}, 5 \mathrm{~b}$ and $5 \mathrm{c}$ for all types of recirculation, $\tau$ is bale residence time, $\dot{v}$ is air flow, $\tau_{k r}$ is the time when the bales were totally burned, $m_{0}$ is bale weight, $\Delta m$ is a change in bale weight over time. Note that expressions in the brackets in the numerator in $(5 \mathrm{a}-\mathrm{c})$ are, according to the second formula in Section 2.3, boiler thermal power with regression coefficients from Tables $4 \mathrm{a}-\mathrm{c}$.

Table 5. Estimation of empirical regression coefficients and analysis of variance of model (5a), (a) no recirculation; (b) recirculation 16.5\%; (c) recirculation 33\%.

\begin{tabular}{ccccclcc}
\hline \multicolumn{7}{c}{ (a) } & \multicolumn{6}{c}{ Level of confidence: $\mathbf{9 5 \%}$, Determination coefficient: $\boldsymbol{R}^{\mathbf{2}}=\mathbf{8 9 . 8 4 \%}$} \\
\hline & Estimate & Standard error & $\boldsymbol{t}$-test & Confidence interval & & Sum of squares & $\boldsymbol{F}$-test \\
\hline$b_{8} *$ & 0.00649 & 0.00014 & 47.3 & $(0.00622,0.00676)$ & Regression & $1,242,130$ & \\
$b_{9}^{*}$ & 12.7634 & 1.4589 & 8.7 & $(9.8978,15.6289)$ & Residual & 17,256 & 20,011 \\
& & & & & Total & $1,259,386$ & \\
\hline
\end{tabular}


Table 5. Cont.

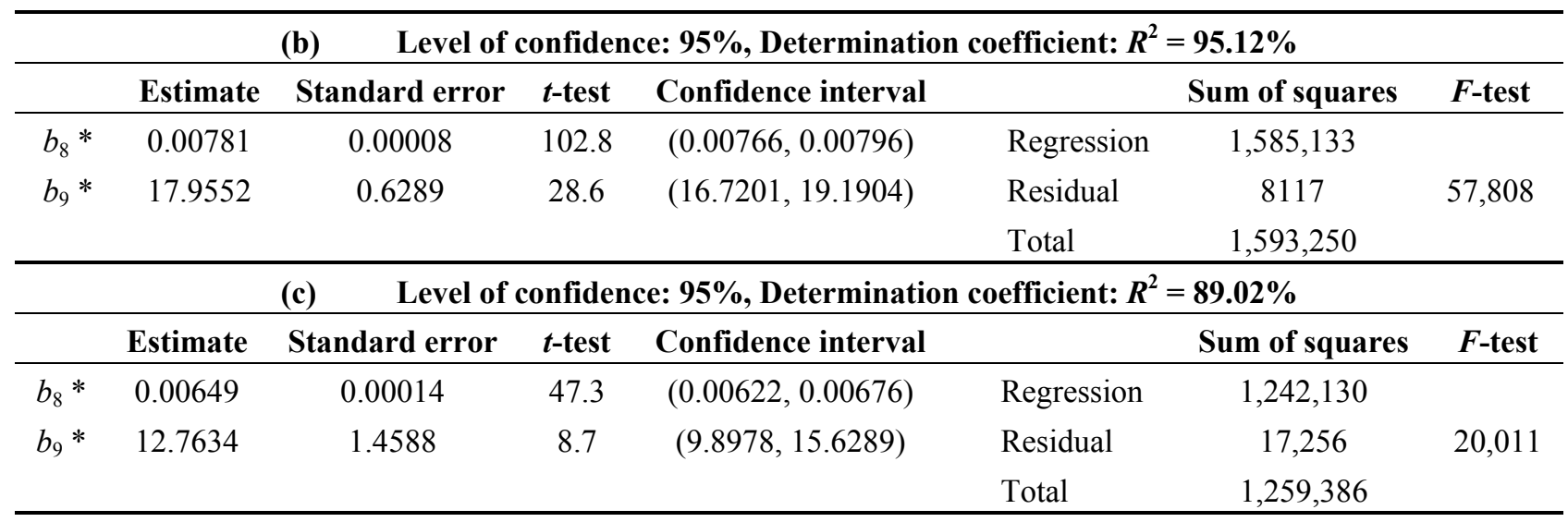

* significant coefficients at significance level of $P<0.05$.

Experimental data of boiler efficiency rate and its graphical interpretation by Formula (5a) is given in Figures 9(a) and 9(b) (for the case of $0 \%$ recirculation), while a graphical interpretation of Formulas (5b) and (5c) is given in Figures 10 and 11, respectively.

Figure 9. (a) Correlation between boiler energy efficiency rate and bale residence time, experimental data, recirculation $0 \%$. (b) Correlation between boiler energy efficiency rate and bale residence time, model (5), recirculation $0 \%$.
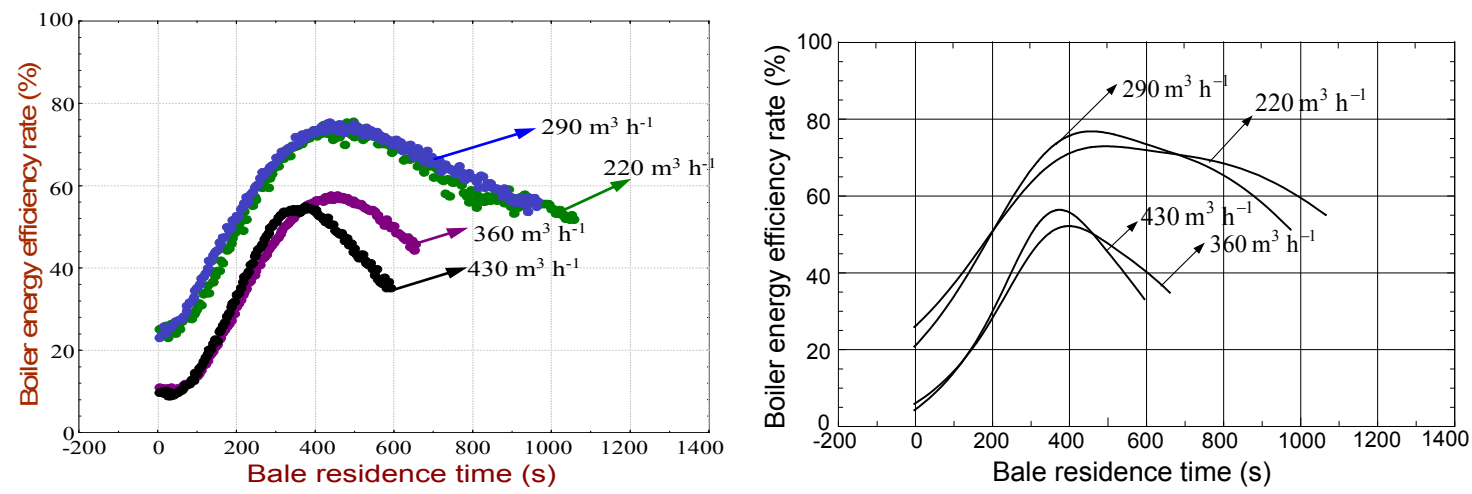

Figure 10. Correlation between boiler energy efficiency rate and bale residence time, model (6), recirculation $16.5 \%$.

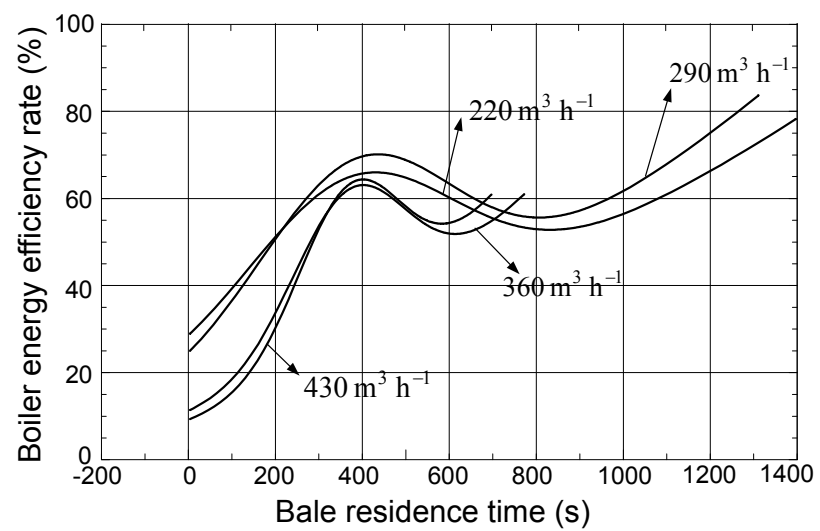


Based on Figures 9(b) and 10, one can conclude that the 220 and $290 \mathrm{~m}^{3} \mathrm{~h}^{-1}$ regimes have the biggest boiler energy efficiency rate in case of $0 \%$ and $16.5 \%$ recirculation. Together with the previous discussion, this makes the 220 and $290 \mathrm{~m}^{3} \mathrm{~h}^{-1}$ regimes the optimal ones. If recirculation is $33 \%$ (Figure 11), the biggest boiler energy efficiency rate is in the $430 \mathrm{~m}^{3} \mathrm{~h}^{-1}$ regime, but now, the bale was completely burned after about 630 seconds. In all other regimes, that time is longer. An increase of combustion product recirculation (in the 220 and $290 \mathrm{~m}^{3} \mathrm{~h}^{-1}$ regimes) causes a small decrease of boiler energy efficiency.

Based on the above discussion, regarding boiler thermal power, the time when a bale is totally burnt and boiler energy efficiency, two regimes can be taken as optimal ones in case of recirculation of 0 and $16.5 \%$ and they are the 220 and $290 \mathrm{~m}^{3} \mathrm{~h}^{-1}$ regimes.

Figure 11. Correlation between boiler energy efficiency rate and bale residence time, model (7), recirculation 33\%.

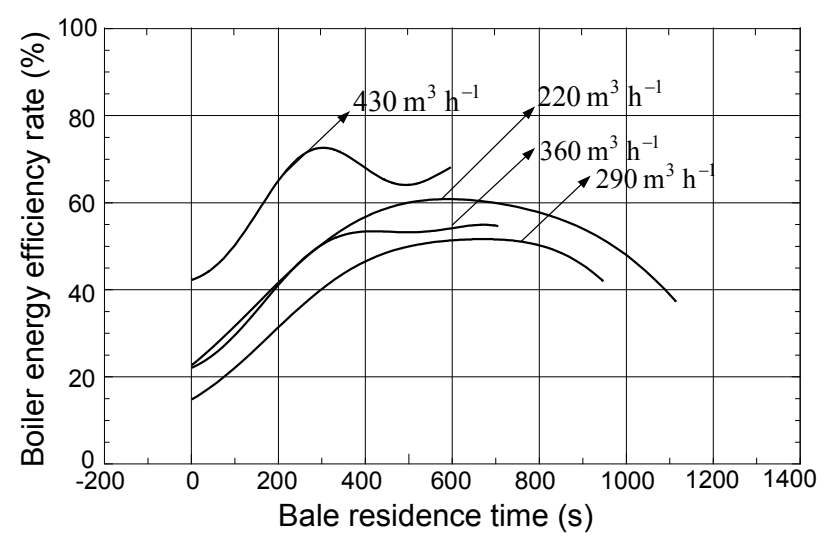

\subsection{Maximum Boiler Thermal Power and Energy Efficiency}

To determine compliance between analyzed regimes and nominal boiler power, it is necessary to find out the maximum achieved boiler power as well as maximum boiler efficiency. In Table 6 , the maximum boiler thermal power, corresponding time when the maximum is reached and the energy efficiency of a boiler for all regimes and all types of recirculation are presented.

Table 6. Maximum boiler thermal power and corresponding boiler energy efficiency rate.

\begin{tabular}{|c|c|c|c|c|c|c|}
\hline \multirow{2}{*}{ Boiler operating regime } & & \multirow{2}{*}{ Recirculation } & \multicolumn{4}{|c|}{ Boiler operating regime $\left(\mathrm{m}^{3} \mathrm{~h}^{-1}\right)$} \\
\hline & & & 220 & 290 & 360 & 430 \\
\hline \multirow{9}{*}{$\begin{array}{l}\text { Time to reach the maximum } \\
\text { thermal power and boiler } \\
\text { energy and corresponding } \\
\text { efficiency rate }\end{array}$} & \multirow{3}{*}{$\tau(\mathrm{s})$} & $0 \%$ & 400 & 388 & 346 & 338 \\
\hline & & $16.5 \%$ & 376 & 373 & 362 & 360 \\
\hline & & $33 \%$ & 434 & 399 & 322 & 286 \\
\hline & \multirow{3}{*}{$P_{\max }(\mathrm{kW})$} & $0 \%$ & 84.05 & 97.97 & 116.96 & 132.19 \\
\hline & & $16.5 \%$ & 68.66 & 84.84 & 112.07 & 133.44 \\
\hline & & $33 \%$ & 68.70 & 83.68 & 89.22 & 101.36 \\
\hline & \multirow{3}{*}{$\eta(\%)$} & $0 \%$ & 72.37 & 76.39 & 51.41 & 56.11 \\
\hline & & $16.5 \%$ & 65.77 & 68.89 & 61.81 & 62.71 \\
\hline & & $33 \%$ & 57.79 & 45.77 & 51.01 & 72.47 \\
\hline
\end{tabular}


Maximum boiler thermal power (reached in the first half of the combustion process) is less than the nominal one in the 220 and $290 \mathrm{~m}^{3} \mathrm{~h}^{-1}$ regimes, which implies that it is enough to have a boiler with a nominal power of $100 \mathrm{~kW}$. In the $430 \mathrm{~m}^{3} \mathrm{~h}^{-1}$ regime, maximum boiler thermal power is greater than the nominal one. It follows that this regime is not appropriate for the considered boiler since a thermal power greater than the nominal one can cause damage to a boiler. The corresponding boiler energy efficiency is the greatest $\left(76.39 \%\right.$ ) in the $290 \mathrm{~m}^{3} \mathrm{~h}^{-1}$ regime with $0 \%$ recirculation. Note that recirculation of $16.5 \%$ decreased maximum boiler thermal power by about 18,13 and $4 \%$ in the 220 , 290 and $360 \mathrm{~m}^{3} \mathrm{~h}^{-1}$ regimes, respectively.

In Table 7, maximum boiler energy efficiency, corresponding time when the maximum is reached and boiler thermal power are presented. Among other regimes, in the $290 \mathrm{~m}^{3} \mathrm{~h}^{-1}$ regime with $0 \%$ recirculation, the maximum boiler energy efficiency is reached (almost 80\%) in the first half of the combustion process.

Table 7. Maximum boiler energy efficiency rate and corresponding boiler thermal power.

\begin{tabular}{lcccccc}
\hline \multirow{2}{*}{ Boiler operating regime } & \multirow{2}{*}{ Recirculation } & \multicolumn{4}{c}{ Boiler operating regime $\left(\mathbf{m}^{\mathbf{3}} \mathbf{h}^{-\mathbf{1}}\right)$} \\
\cline { 3 - 7 } & & $0 \%$ & 490 & 454 & 396 & 372 \\
& \multirow{3}{*}{$\tau(\mathrm{s})$} & $16.5 \%$ & 437 & 433 & 400 & 399 \\
& & $33 \%$ & 595 & 667 & 421 & 497 \\
\cline { 3 - 7 } Time to reach the maximum & & $0 \%$ & 74.10 & 77.99 & 53.30 & 57.53 \\
boiler energy efficiency rate & \multirow{2}{*}{$\eta_{\max }(\%)$} & $16.5 \%$ & 66.83 & 70.27 & 63.09 & 64.41 \\
and corresponding thermal & & $33 \%$ & 60.62 & 51.18 & 53.03 & 63.96 \\
nower & \multirow{3}{*}{$P(\mathrm{~kW})$} & $0 \%$ & 81.59 & 95.63 & 112.59 & 128.94 \\
& & $16.5 \%$ & 67.57 & 83.23 & 109.73 & 129.95 \\
& & $33 \%$ & 37.90 & 69.01 & 84.05 & 79.62 \\
\hline
\end{tabular}

Note that $16.5 \%$ recirculation decreased maximum boiler energy efficiency by about $10 \%$ in the 220 and $290 \mathrm{~m}^{3} \mathrm{~h}^{-1}$ regimes, and increased it by about $18 \%$ in the $360 \mathrm{~m}^{3} \mathrm{~h}^{-1}$ regime, but this efficiency is still less than one obtained in the 220 and $290 \mathrm{~m}^{3} \mathrm{~h}^{-1}$ regimes.

Recirculation of the combustion products is not introduced to reduce emissions of nitrogen oxides from the firebox (although that is partially achieved), but to make the combustion of biomass bales longer, and to affect boiler thermal power and energy efficiency. As it can be seen from Tables 6 and 7, these intentions are partially fulfilled. Regarding Tables 6 and 7, the recirculation in case of low air flow gave significantly worse results in the wheat straw bale combustion process. Lower boiler thermal power was achieved as well as lower boiler energy efficiency. In the case of $16.5 \%$ recirculation, with the increase in the total amount of air injected into the firebox, a positive impact of the preheated air on the combustion parameters was achieved, such as $\mathrm{s}$ higher maximum boiler thermal power and energy efficiency compared to the case when there is no recirculation. In the case of $33 \%$ recirculation, the expected results were not achieved, but in this regime, it can be seen that better indicators of bale burning are also obtained at higher air flow. This can largely be explained by the positive influence of air preheating on combustion of wheat straw bales. From the above discussion, one can conclude that recirculation of $33 \%$ is not adequate and should be avoided. Combustion of bales using higher air flow regimes are desirable when recirculation is $16.5 \%$. 
All figures in this study, which are obtained by mathematical models, are processed in the package Mathematica 6, which is, as well as package Statistica 10, very applicable in the various problems related to agriculture [25-28].

\section{Conclusions}

Boiler thermal power ranges between 63.47 and $90.90 \mathrm{~kW}$ if there is no combustion products recirculation. Boiler thermal power ranges between 57.86 and $88.12 \mathrm{~kW}$ with $16.5 \%$ recirculation and from 55.65 to $84.98 \mathrm{~kW}$ with $33 \%$ recirculation. Boiler energy efficiency varies from 36.57 to $60 \%$ interval if there is no recirculation, i.e., from 40.60 to $66.08 \%$ if there is $16.5 \%$ recirculation (from 41.64 to $49.85 \%$ in the case of $33 \%$ recirculation). The results point to the fact that the optimal operating regimes are obtained when the air flow through the firebox reaches 220 and $290 \mathrm{~m}^{3} \mathrm{~h}^{-1}$, if the recirculation is $16.5 \%$ and $0 \%$, respectively. Recirculation of $33 \%$ causes worse boiler characteristics. These results correspond to the results given in [21], i.e., boiler energy efficiency rate ranges between 70 and $80 \%$ for smaller boilers which are fed manually with baled biomass.

The presented mathematical models can be perceived as valid for the given boiler plant and the conditions under which the experiments were conducted. The applications of these mathematical models in practice can be multiple. Apart from providing basic information with the aim of improving boiler plant energy efficiency, these mathematical models can be applied in the construction of the future plants, as well as for the reconstruction and mechanization of the existing ones.

\section{Acknowledgement}

This paper was financed by the Ministry of Education and Science, the Republic of Serbia, Grant No. TR-31046, TR-31058, TR-37017 and III-42011, 2011-2014.

\section{References}

1. Pešenjanski, I. Kinetics of Straw Bales Combustion. Master Thesis, University of Novi Sad, Novi Sad, Serbia, 2000.

2. Cherubin, F. The biorefinery concept: Using biomass instead of oil for producing energy and chemicals. Energy Convers. Manag. 2010, 51, 1412-1421.

3. Janić, T. Kinetics of Wheat Straw Combustion. Ph.D. Thesis, University of Novi Sad, Novi Sad, Serbia, 2000.

4. Šefčić, Đ. Research Criteria for Evaluating the Effectiveness of Evaluation Straw Process. Ph.D. Thesis, University of Novi Sad: Novi Sad, Serbia, 1991.

5. Haykiri-Açma, H. Combustion characteristics of different biomass materials. Energy Convers. Manag. 2003, 44, 155-162.

6. Zhaosheng, Y.; Xiaoqian, M.; Ao, L. Thermogravimetric analysis of rice and wheat straw catalytic combustion in air- and oxygen-enriched atmospheres. Energy Convers. Manag. 2009, 50, 561-566.

7. Gustavsson, L.; Borjesson, P.; Johansson, B.; Svenningsson, P. Reducing $\mathrm{CO}_{2}$ emissions by substituting biomass for fossil fuels. Energy 1995, 20, 1097-1113. 
8. Werther, J.; Saenger, M.; Hartge, E.U.; Ogada, T.; Siagi, Z. Combustion of agricultural residues. Prog. Energy Combust. Sci. 2000, 26, 1-27.

9. Easterly, L.J.; Burnham, M. Overview of biomass and waste fuel resources for power production. Biomass Bioenergy 1996, 10, 79-92.

10. Gohlke, O.; Busch, M. Reduction of combustion by-products in WTE plants: $\mathrm{O}_{2}$ enrichment of underfire air in the M S process. Chemosphere 2001, 42, 545-550.

11. Henrich, E.; Burkle, S.; Meza-Renken, Z.I.; Rumpel, S. Combustion and gasification kinetics of pyrolysis chars from waste and biomass. J. Anal. Appl. Pyrolysis 1999, 49, 221-241.

12. Zhou, W.; Li, Z.; Zhao, G.; Zhang, F.; Zhu, Q. Effect of air preheating and fuel moisture on combustion characteristics of corn straw in a fixed bed. Energy Convers. Manag. 2008, 49, 3560-3565.

13. Kristensen, E.F.; Kristensen, J.K. Development and test of small-scale batch-fired straw boilers in Denmark. Biomass Bioenergy 2004, 26, 561-569.

14. Khor, A.; Ryu, C.; Yang, Y.B.; Sharifi, V.N.; Swithenbank, J. Straw combustion in a fixed bed combustor. Fuel 2007, 86, 152-160.

15. Zhou, H.; Jensen, A.D.; Glarborg, P.; Jensen, P.A.; Kavaliauskas A. Numerical modeling of straw combustion in a fixed bed. Fuel 2005, 84, 389-403.

16. Zhaosheng, Y.; Xiaoqian, M.; Yanfen, L. Mathematical modeling of combustion in a grate-fired boiler burning straw and effect of operating conditions under air- and oxygen-enriched atmospheres. Renew. Energy 2010, 35, 895-903.

17. Bubenheim, D.L.; Patterson, M.; Wignarajah, K.; Flynn, M. Incineration of biomass and utilization of product gas as a $\mathrm{CO}_{2}$ source for crop production in closed systems: gas quality and phytotoxicity. Adv. Space Res. 1997, 20, 1799-2054.

18. Brkić, Lj.; Živanović, T.; Tucaković, D. Thermal Calculations on Steam Boilers; Faculty of Mechanical Engineering, University of Belgrade: Belgrade, Serbia, 2006.

19. OFI; Austrian Research Institute for Chemistry and Technology. The Laboratory Report of Composition of Wheat Straw from Serbia. OFI: Vienna, Austria, 2011.

20. Dedović, N.; Igić, S.; Janić, T. Energetic efficiency of boiler for combustion biomass by recirculation of combustion products and mathematical models. Contemp. Agric. Eng. 2008, 34, 220-226.

21. Dedović, N.; Igić, S.; Matić-Kekić, S.; Janić, T. Excess air rate during the straw bale combustion and review of mathematical models. Contemp. Agric. Eng. 2010, 36, 344-356.

22. Igić, S. Impact of Sort and Condition of Baled Straw, Incoming Air Quantity and Composition, on Boiler Energy Efficiency. Ph.D. Thesis, University of Novi Sad, Novi Sad, Serbia, 2008.

23. Strasser, H. Mathematical Theory of Statistics; De Gruyter: Berlin, Germany, New York, NY, USA, 1985.

24. Terzić, Ž. Effect of biomass type to work boiler. Master Thesis, University of Novi Sad, Novi Sad, Serbia, 2008.

25. Dedović, N.; Matić-Kekić, S.; Ponjičan, O.; Karadžić, B. New approach to border line evaluations for whole sample of Williams pear (Pyrus communis). Comput. Electron. Agric. 2011, 79, 94-101. 
26. Tomić, M.; Matić-Kekić, S.; Savin, L.; Desnica, E.; Dedović, N.; Simikic, M.; Ponjičan, O.; Asonja, A. Optimization of the locations of overhaul capacities for agricultural engineering in Serbia by applying integer programming. Afr. J. Agric. Res. 2011, 6, 3346-3354.

27. Babić, L.; Matić-Kekić, S.; Dedović, N.; Babić, M.; Pavkov, I. Surface area and volume modeling of the williams pear (Pyrus communis). Int. J. Food Prop. 2011, doi:10.1080/10942912.2010.506020.

28. Simikić, M.; Dedović, N.; Savin, L.; Томић, M.; Silleli, H.; Ponjičan, O. Power delivery efficiency in the eccentric traction of a wheeled tractor. Turk. J. Agric. For. 2012, in press.

(C) 2012 by the authors; licensee MDPI, Basel, Switzerland. This article is an open access article distributed under the terms and conditions of the Creative Commons Attribution license (http://creativecommons.org/licenses/by/3.0/). 